\title{
A laboratory study of backfilling bord and pillar voids using fly ash slurry
}

\section{D.J. Williams The University of Queensland, Australia}

M. Ramlackhan The University of Queensland, Australia

D. Spriggs The University of Queensland, Australia

H. Alehossein CSIRO, Australia

B. Shen CSIRO, Australia

\begin{abstract}
In various locations worldwide, fly ash slurry has been injected into underground bord and pillar coal mine workings to provide support, and the method was recently used successfully for the Ipswich Motorway upgrade in southeast Queensland, Australia. This paper describes laboratory testing, and the results obtained, aimed at achieving an improved understanding of the backfilling processes and to provide guidance for the effective application of fly ash slurry injection to stabilise bord and pillar underground coal workings and allow the safe development of the surface.
\end{abstract}

\section{Introduction}

\subsection{Bord and pillar underground coal workings}

Early bord and pillar underground coal workings were quite extensive in the Ipswich Coalfields of southeast Queensland. Shown schematically in Figure 1(a), bord and pillar operations relied on leaving a substantial amount of coal in the ground as pillars to support the roof and ensure safe operations. However, on retreat towards the end of underground mining operations, the pillars were often 'robbed' to extract more coal, transferring more stress onto the remaining pillar dimensions and reducing their capacity to support the roof. Over time, the pillars tend to fret and spall, further reducing their capacity. Typically, the abandoned workings will flood as the groundwater recovers. Flooding has the potential to soften the roof and the floor and weaken clay-rich coal exposed in the pillars, further reducing the capacity of the pillars.

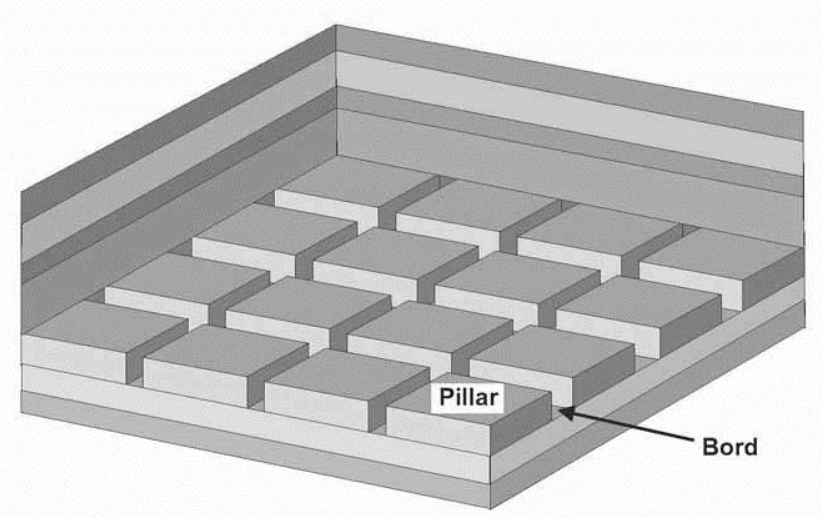

(a)

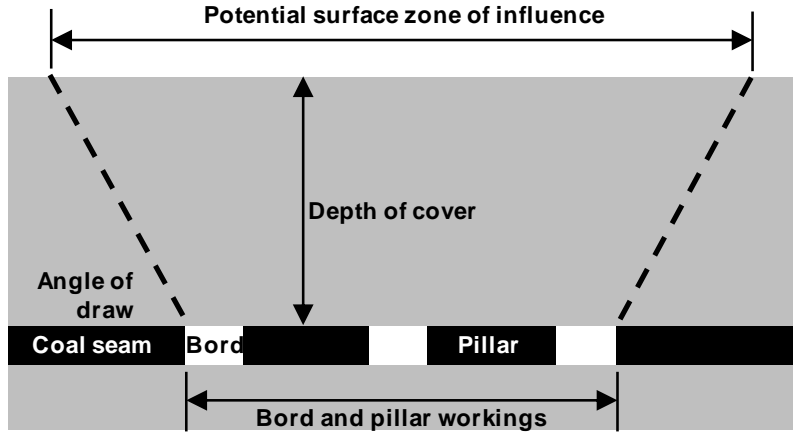

(b)

Figure 1 Bord and pillar underground coal workings: (a) schematic of workings; and (b) schematic of potential zone of surface influence 
The compression and partial or complete collapse of pillars is reflected to the surface as subsidence and sinkholes, over a zone of influence defined by the 'angle of draw', as shown in Figure 1(b). Since the support offered by the pillars is not uniform, the subsidence tends to be differential, leading to differential surface subsidence and damage to any structures on the surface.

\subsection{Potential for backfilling of bord and pillar workings using fly ash}

Backfilling of the bord and pillar voids, for example with coal-fired power station fly ash, can be effective in providing the support necessary to limit or prevent surface subsidence and sinkholes, and hence allow the safe development of areas underlain by bord and pillar underground coal workings. Fly ash injection into underground coal workings has been trialled at a few underground coal mines in Australia (including Awaba, as part of an ACARP Project C7033, 2001) and at mines in South Africa, the United Kingdom and Germany. In the past, the main purpose of fly ash injection was disposal of the material, to reduce the need for surface storage. At Awaba, fly ash was injected at a range of solids concentrations, often leading to only partial backfilling of the underground voids and the separation of solids and water. This limited the potential to provide support to underground voids. Advances in paste backfill in underground metalliferous mines over the last decade or so offer the potential to stabilise underground coal workings using fly ash as a paste.

Dodd (2005) reported on pressurised grout remote backfilling used since 1991 for stabilising collapsing underground coal mines in North Dakota, where there are more than 600 abandoned mines. In this technique, a cementitious (fly ash plus Portland cement) grout is pumped through cased drill holes directly into mine cavities to fill them and thereby stabilise the surface from collapse. Fly ash is $18 \%$ cheaper than cement and it also improves the flowability of the grout, because the spherical fly ash particles act like ball bearings.

Fly ash is about $80-90 \%$ composed of spherical glass particles formed from molten clays, shales, limestone and dolomite. These small spherical particles combine with calcium hydroxide to form calcium silicate hydrate, the principal binder of cement. Fly ash is classified by its cementitious parameters by the American Society for Testing and Materials (ASTM). Fly ash is a pozzolan, which forms cement-like compounds when mixed with lime and water. Fly ash is somewhat similar to volcanic ash used to produce the earliest cements about 2,300 years ago near the Italian town of Pozzuoli. The use of fly ash adds to the compressive strength of the grout, and also reduces shrinkage and slows setting time. Another important reason for using fly ash is recycling; every tonne of fly ash used beneficially is one not disposed in a purpose-built storage facility.

However, fly ash can potentially pose environmental and health risks. It can contain trace amounts of several toxic elements including boron, molybdenum, selenium and arsenic. These elements could contaminate soil and water. Portland cement also contains these elements and they can occur naturally in soil and water. If used responsibly, fly ash is a safe product and can be used safely with very limited chances of polluting soils or water. After grout containing fly ash hardens it is fairly inert. Research conducted by North Dakota Public Service Commission (Wald and Beechie, 1996) found that grout mixes using fly ash often leached lower concentrations of trace minerals than cement-only grout. This research also indicated that, depending on the source of fly ash, leachate from hardened grout could meet safe drinking water standards for heavy metal concentrations.

Because of lateral fluid pressure at the time of placement, grout is generally placed in lifts not exceeding $1.2-1.5 \mathrm{~m}$. Theoretically, once grout placed against a retaining wall or abutment has hardened, the lateral fluid pressure exerted during placement and initial curing should be significantly reduced.

Ward et al. (2006) reviewed fly ash open cut and underground mine backfill practice in Australia. The review included the geotechnical and geochemical characterisation of a range of Australian fly ash materials, overseas fly ash, the interaction of fly ash with water, regulatory issues, the environmental impact of fly ash emplacement, fly ash mine backfill, and other applications. The review concluded that there has been limited fly ash mine backfill in Australia and that there is considerable potential for an increase.

\section{Details of fly ash testing}

The testing carried out on fly ash sampled in three $200 \mathrm{~L}$ drums from a stockpile at Swanbank Power Station, near Ipswich in Queensland, comprised: (i) laboratory characterisation testing of the fly ash; (ii) laboratory geotechnical parameter testing of the fly ash; (iii) laboratory flume testing of slurried fly ash; and (iv) field 
profiling, and sampling and laboratory testing, of an old fly ash beach at Swanbank Power Station. The details of the fly ash testing are described in the following paragraphs.

\subsection{Laboratory characterisation testing}

Laboratory characterisation testing of the Swanbank fly ash was carried out in accordance with AS 1289 where appropriate. It included the determination of the following.

- As-sampled total moisture content (= [mass of water]/[mass of solids + water $]$, or $100-\%$ solids by mass $=\{$ mass of solids $\} /\{$ mass of solids + water $\}]$, expressed as a $\%$; this being the conventional expression for moisture content used in a mining context).

- Particle size distribution analysis by sieving (air-dry and wet-dispersed) and (dispersed) hydrometer.

- Atterberg limits.

- Specific gravity (by pychnometer using helium).

- Emerson crumb testing.

- $\mathrm{pH}$ and Electrical conductivity testing (carried out on pastes of 5 [deionised water]: 1 [solids]).

\subsection{Laboratory geotechnical parameter testing}

Laboratory geotechnical parameter testing of the Swanbank fly ash, carried out in accordance with AS 1289 where appropriate, included settling column testing and oedometer testing.

The settling column tests were carried out in $1,000 \mathrm{~cm}^{3}$ measuring cylinders on Swanbank fly ash at initial \% solids of 55, 50, 45 and $35 \%$, and the surface of the settling solids was monitored over time until settling ceased. The data collected were then used to determine average \% solids, total moisture content, and dry density plots with time.

Oedometer test was carried out in a standard $76 \mathrm{~mm}$ diameter ring on Swanbank fly ash at an initial \% solids of $50 \%$, under applied stresses of $1,10,20,50$ and $100 \mathrm{kPa}$, with each stress maintained until primary consolidation had ceased, before the next increment was applied.

\subsection{Laboratory flume testing}

Beaching and settling of Swanbank fly ash, at a range of initial \% solids, was carried out in a laboratory flume measuring $2 \mathrm{~m}$ long, by $0.6 \mathrm{~m}$ wide by $0.6 \mathrm{~m}$ high (Figure 2). Four series of tests were carried out in the laboratory flume: (i) open-ended, sub-aerial (unflooded), testing without a constriction, to simulate backfilling of a large, unflooded underground void; (ii) open-ended, sub-aerial testing through a constriction, to simulate backfilling of a narrow, unflooded underground void; (iii) open-ended, sub-aqueous (flooded) testing without a constriction, to simulate backfilling of a large, flooded underground void; and (iv) closedended, sub-aqueous, constricted testing under a head of fly ash slurry, to simulate backfilling of a closedended, flooded underground void. Preliminary testing showed that at between 60 and $65 \%$ solids Swanbank fly ash slurry ceased to flow readily. For the open-ended tests, initial \% solids of 55, 50, 45, 35 and $15 \%$ were tested, restricted by the limited flowability of the fly ash above $55 \%$ solids. For the closed-ended tests, initial \% solids of 50\% (under low and high heads of fly ash slurry) and 60\% (under a high head of fly ash slurry) were tested, with flowability at $60 \%$ solids aided by the head of fly ash slurry applied.

The fly ash slurry was prepared by mixing air-dried fly ash with tap water to the required \% solids, using a mechanical mixer. Sufficient slurry was prepared in advance in $20 \mathrm{~L}$ buckets for each flume test. Prior to introducing the slurried fly ash into the delivery funnel of the flume, each bucket was re-mixed using the mechanical mixer. Buckets of slurry were then poured into the flume as continuously as possible.

\subsubsection{Open-ended, unflooded and flooded beach tests}

For the sub-aerial (unflooded) beach tests, the lip at the end of the flume was a nominal $5 \mathrm{~mm}$ high, and fly ash delivery was continued until slurried fly ash just started to overflow this lip into a collector and thence to a spare $20 \mathrm{~L}$ bucket, to develop a beach profile along the full length the flume. A number of unflooded flume 
tests were carried out with a constricted $300 \mathrm{~mm}$ wide central opening over the central third of the flume length, to simulate an underground bord and pillar void. The constriction was formed by two $50 \mathrm{~mm}$ high by $150 \mathrm{~mm}$ wide polystyrene blocks placed either side of the flume to halve the width through which the slurried fly ash had to pass. They were held down with a sheet of Perspex, weighted down. For the subaqueous (flooded) beach tests, the lip at the end of the flume was raised to a nominal $50 \mathrm{~mm}$ and the flume pre-filled with tap water. These tests were continued until fly ash solids reached the end of the flume, and stopped before they overflowed the raised end lip of the flume.

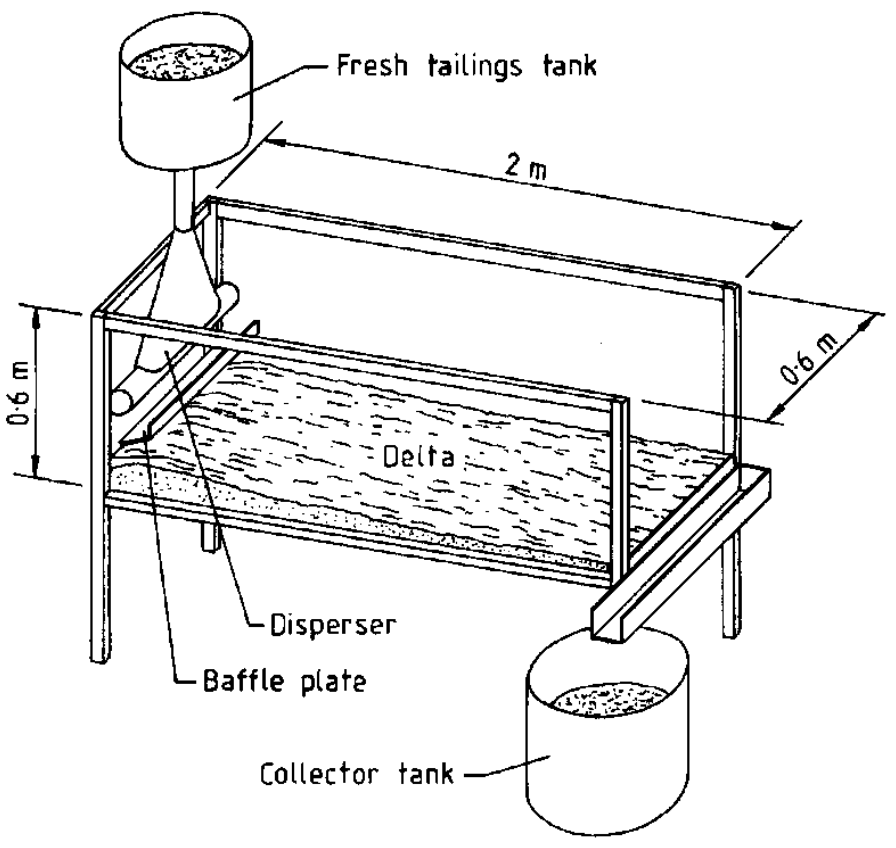

(a)

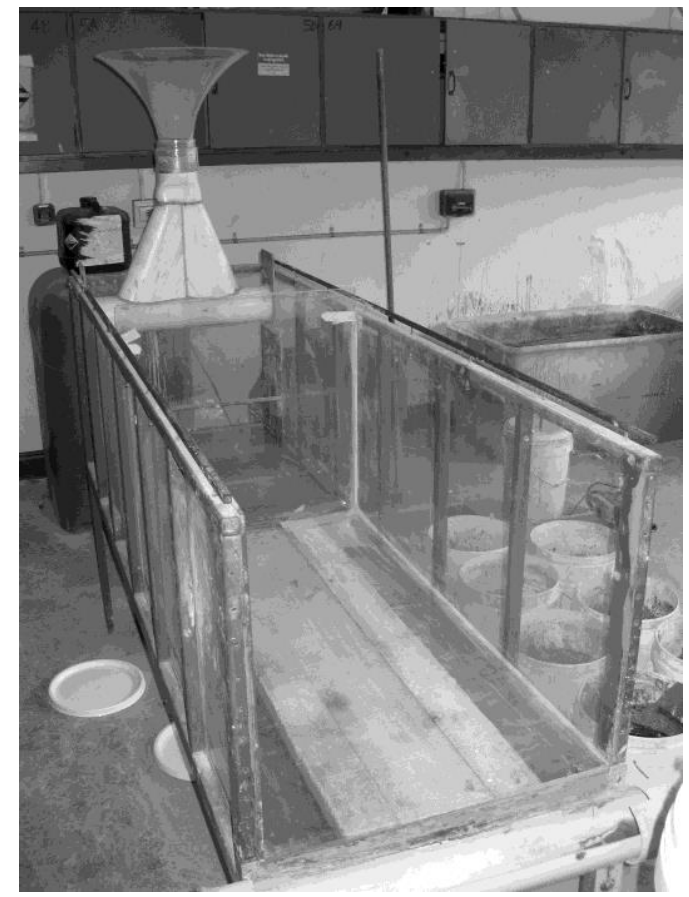

(b)

Figure 2 Laboratory flume: (a) schematic; and (b) view of a test

After allowing sufficient time (usually overnight) for the deposited fly ash solids to settle out on the beach, the longitudinal beach profile was measured at quarter points across the width of the flume (each set of these were similar, and only the central beach profiles are reported herein).

\subsubsection{Closed-ended, flooded beach tests, with a constriction and a head of fly ash slurry}

To simulate a pair of closed-ended bord and pillar voids, a central $50 \mathrm{~mm}$ high by $400 \mathrm{~mm}$ wide polystyrene block extending over the lower two-thirds of its length was placed in the base of the flume, forming two $120 \mathrm{~mm}$ wide perimeter openings (40\% opening), and covered with a sheet of Perspex, weighted down and sealed to the sides and end of the flume. In order to apply a head of fly ash slurry to the constricted, closedended flume, a Perspex divider was placed above the constriction to the top of the flume (Figure 3 ).

\subsection{Field profiling, sampling and testing, of an old fly ash beach}

Recognising that small-scale laboratory flume testing can over-estimate field beach slopes, a drained and desiccated beach at Swanbank Power Station was profiled, sampled and subjected to laboratory characterisation testing. The fly ash is understood to have been discharged at an initial \% solids of about $15 \%$ by mass. The $355 \mathrm{~m}$ long beach was surveyed and sampled at approximately $25 \mathrm{~m}$ intervals, and the samples subjected to total moisture content determination and dry sieving analysis. 


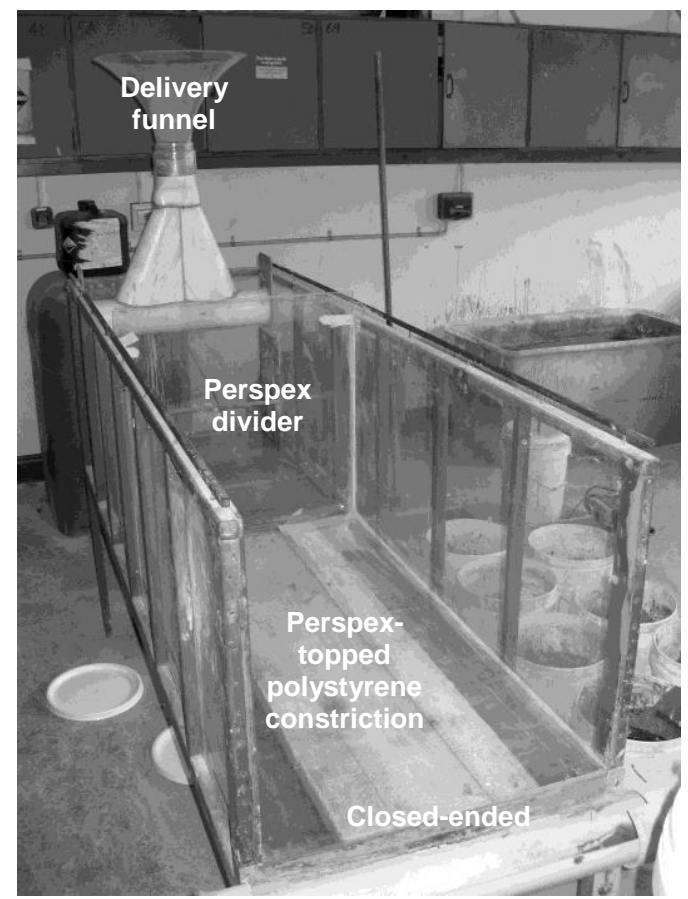

Figure 3 Laboratory flume showing central constriction topped with Perspex, and Perspex divider

\section{$3 \quad$ Results of fly ash testing}

The results of the testing carried out on Swanbank fly ash are presented in the following paragraphs.

\subsection{Laboratory characterisation}

The as-supplied moisture states of the three $200 \mathrm{~L}$ drum samples of Swanbank fly ash are given in Table 1.

Table 1 As-sampled moisture state of Swanbank fly ash

\begin{tabular}{lllll}
\hline Parameter & Sample 1 & Sample 2 & Sample 3 & Averages \\
\hline Total moisture content $(\%)$ & 28.7 & 29.1 & 26.6 & $\mathbf{2 8 . 1} \pm \mathbf{1 . 3}$ \\
$\%$ solids by mass & 71.3 & 70.9 & 73.4 & $\mathbf{7 1 . 9} \pm \mathbf{1 . 3}$ \\
\hline
\end{tabular}

Figure 4 shows the range of particle size distribution curves obtained for the three drums of Swanbank fly ash sampled for laboratory testing. The addition of dispersant (in accordance with the AS 1289 standard method) prior to sieving is seen to increase the fines content (silt and clay-size) by about $5 \%$ by mass. This is due to the washing of fines off the coarser particles. Dispersant was also added to the fines prior to hydrometer analysis, and this analysis indicated a higher fines content still (by about a further 5\%), although some of this apparent increase may be due to hindered settling. Emerson crumb testing of three replicates of the three drum samples gave an Emerson Class No. of 6 for all tests, indicating a medium potential for erosion.

Swanbank fly ash was found to have an average liquid limit of $47.9 \pm 2 \%$, to be non-plastic (no plastic limit could be determined), and hence to have an plasticity index of $47.9 \pm 2 \%$. According to the particle size distribution data, Swanbank fly ash classifies as a gravelly, clayey, sandy silt-sized material comprising spherical particles, with about $6 \%$ gravel-sized, $17 \%$ sand-sized, $64 \%$ silt-sized, and $13 \%$ clay-sized particles. According to the Atterberg limit data it classifies as CL (gravelly, sandy, silty clay of low plasticity), although it is clearly predominantly a silt. Swanbank fly ash was found to have an average specific gravity of $2.09 \pm 0.02$, substantially less than that of normal mineral matter (being 2.65-2.7). Table 2 shows the $\mathrm{pH}$ and electrical conductivity values obtained for Swanbank fly ash. Swanbank fly ash has an alkaline $\mathrm{pH}$ averaging $9.09 \pm 0.07$, and a moderate electrical conductivity averaging $351 \pm 25 \mu \mathrm{S} / \mathrm{cm}$. 


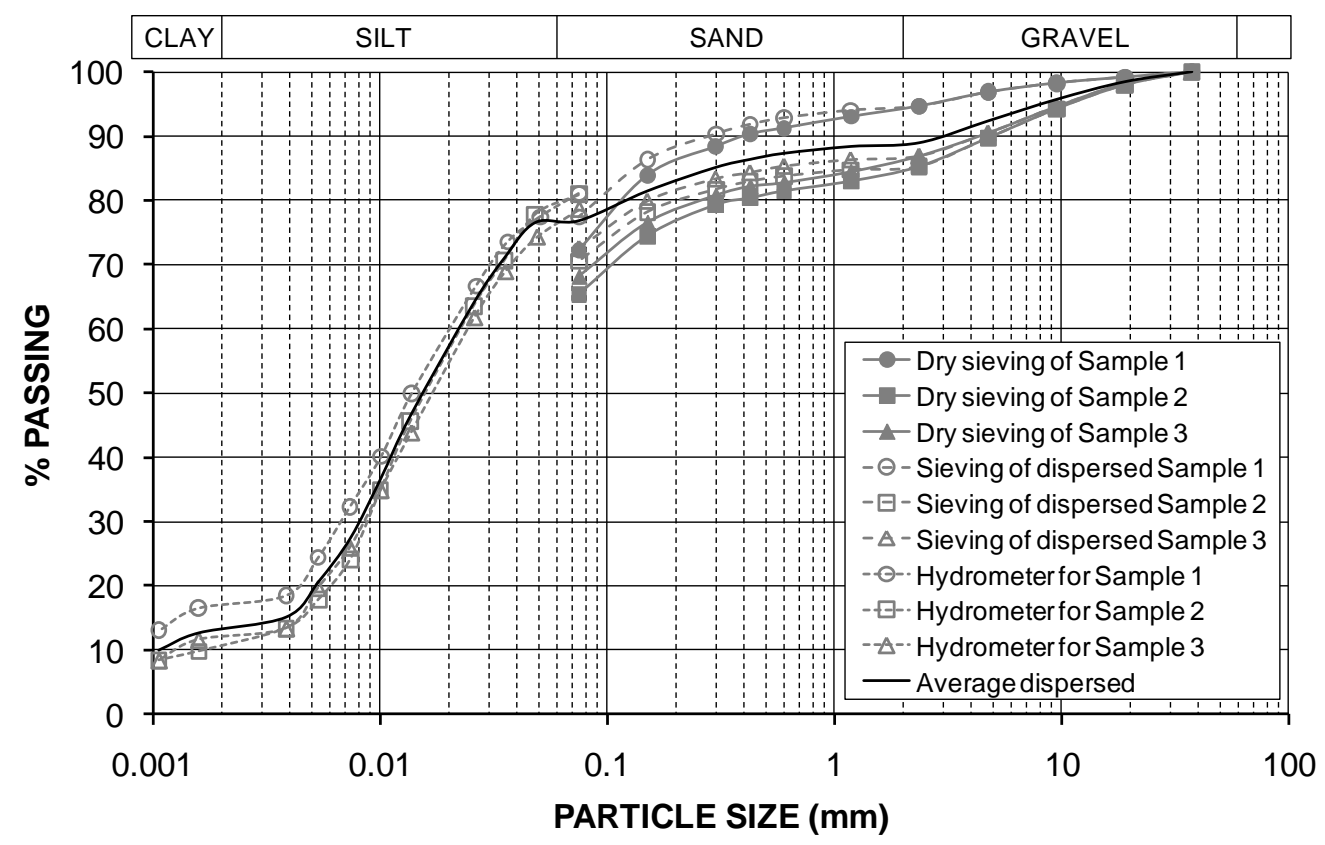

Figure 4 Particle size distribution curves for Swanbank fly ash

Table 2 Measured pH and electrical conductivity values of Swanbank fly ash

\begin{tabular}{lll}
\hline Sample & $\mathbf{p H}$ & Electrical Conductivity $(\boldsymbol{\mu S} / \mathbf{c m})$ \\
\hline 1 & 9.01 & 381 \\
2 & 9.14 & 332 \\
3 & 9.02 & 340 \\
Averages & $\mathbf{9 . 0 9} \pm \mathbf{0 . 0 7}$ & $\mathbf{3 5 1} \pm \mathbf{2 5}$ \\
\hline
\end{tabular}

\subsection{Laboratory geotechnical parameters}

\subsubsection{Settling column results}

The results of the settling column tests are summarised in Table 3 and presented as a plot of average total moisture content versus time plotted to a $\log _{10}$ scale in Figure 5. For all initial \% solids tested $(55,50,45$, and 35\%), settling was complete within 150-300 minutes. The final \% solids decreased slightly with decreasing initial \% solids ( $61.7 \%$ solids from $55 \%$ solids initially to $60.4 \%$ solids from $35 \%$ solids initially), as did the dry and wet densities, while the final total moisture content increased slightly with decreasing initial \% solids. The initial wet density (which drives settling) varied least with initial \% solids, which explains the only slight variation in the final \% solids, total moisture contents and dry densities. 
Table 3 Initial and final average \% solids, total moisture content, dry density and wet density on column settling of Swanbank fly ash from a slurry

\begin{tabular}{llllllll}
\hline \% Solids & & \multicolumn{2}{c}{$\begin{array}{l}\text { Total Moisture } \\
\text { Content }(\mathbf{\%})\end{array}$} & $\begin{array}{l}\text { Dry Density } \\
\left(\mathbf{g} / \mathbf{c m}^{\mathbf{3}}\right)\end{array}$ & \multicolumn{3}{l}{$\begin{array}{l}\text { Wet Density } \\
\left(\mathbf{g} / \mathbf{c m}^{\mathbf{3}}\right)\end{array}$} \\
\hline Initial & Final & Initial & Final & Initial & Final & Initial & Final \\
\hline 55 & 61.7 & 45 & 38.3 & 0.771 & 0.909 & 1.402 & 1.473 \\
50 & 61.3 & 50 & 38.7 & 0.676 & 0.902 & 1.352 & 1.470 \\
45 & 60.7 & 55 & 39.3 & 0.588 & 0.888 & 1.307 & 1.463 \\
35 & 60.4 & 65 & 39.6 & 0.428 & 0.883 & 1.223 & 1.460 \\
\hline
\end{tabular}

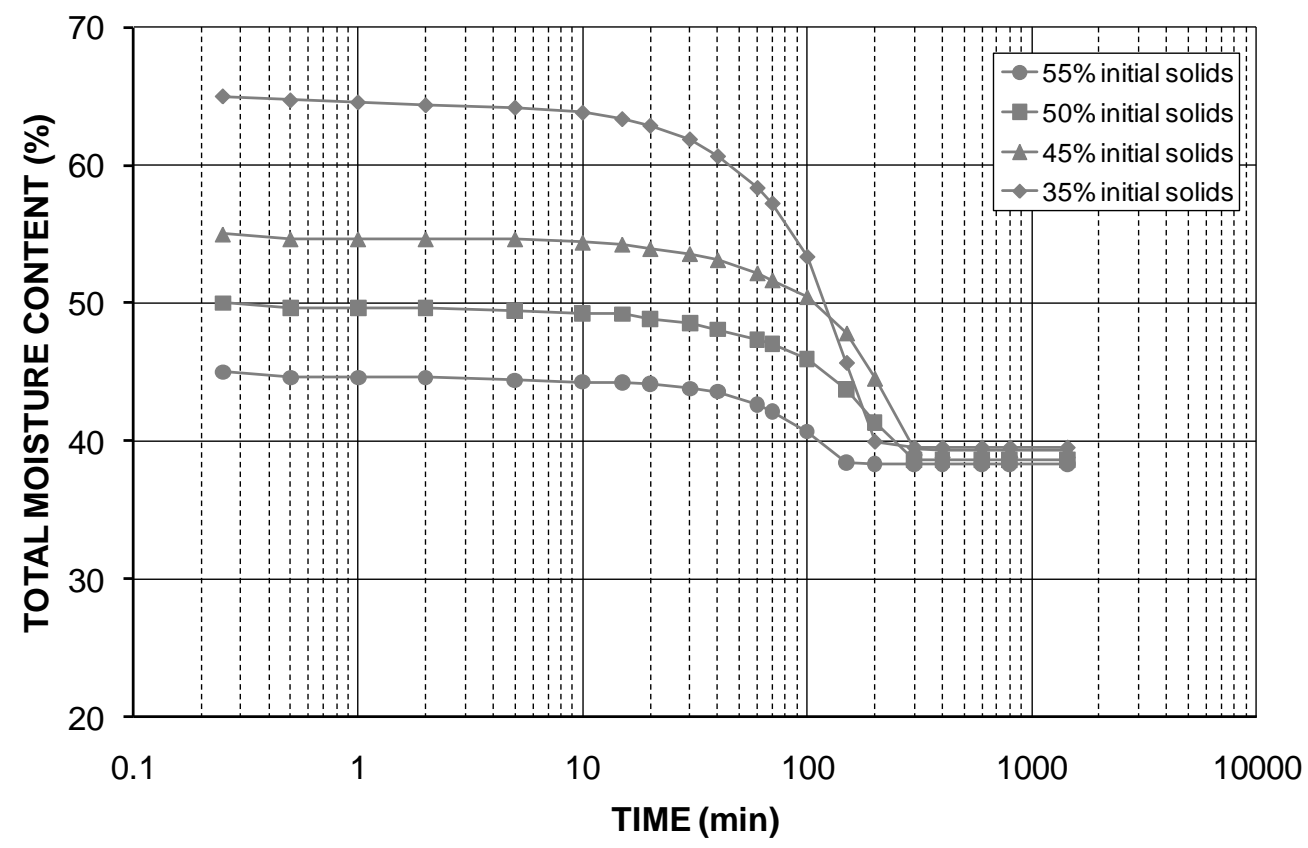

Figure 5 Average total moisture content of settling Swanbank fly ash solids versus time plotted to a $\log _{10}$ scale for various initial \% solids

\subsubsection{Oedometer results}

From the end-points of the oedometer test effective stress increments applied to Swanbank fly ash initially at $50 \%$ solids (initial void ratio $\mathrm{e}_{0}$ of 2.09) indicated a very low compression index $\mathrm{C}_{\mathrm{c}}$ of 0.0455 . The Skempton (1969) empirical correlation between $\mathrm{C}_{\mathrm{c}}$ and liquid limit $\left(\mathrm{w}_{\mathrm{L}}\right)$ :

$$
\mathrm{C}_{\mathrm{c}} \sim 0.009\left(\mathrm{w}_{\mathrm{L}}-10\right)
$$

suggests a value for $\mathrm{C}_{\mathrm{c}}$ for Swanbank fly ash of 0.32 , comparable to $\mathrm{C}_{\mathrm{c}}$ values of greater than 0.3 typically expected for soft clays. However, the oedometer-determined $\mathrm{C}_{\mathrm{c}}$ value of 0.0455 for Swanbank fly ash is very much lower than that suggested by Equation (1) and typical values for soft clays, which may be explained by the high silt, sand and gravel-size fractions of Swanbank fly ash.

Table 4 summarises the oedometer test parameters obtained for Swanbank fly ash. The coefficient of consolidation $c_{v}$ values for Swanbank fly ash are about an order of magnitude higher than the typical value for kaolin of $2.6 \mathrm{~m}^{2} / \mathrm{yr}$. The coefficient of volume decrease $\mathrm{m}_{\mathrm{v}}$ values for Swanbank fly ash correspond to the most compressible (high) end of the range expected for normally consolidated (soft) clays of from $0.3-1.5 \mathrm{~m}^{2} / \mathrm{MN}$. The hydraulic conductivity $\mathrm{k}$ values for Swanbank fly ash are about an order of magnitude higher than the range expected for normally consolidated (soft) clays of from $0.24 \times 10^{-9}$ to $1.2 \times 10^{-9} \mathrm{~m} / \mathrm{s}$. 
Table 4 Oedometer test parameters for Swanbank fly ash

\begin{tabular}{|c|c|c|c|c|c|c|}
\hline \multirow[t]{2}{*}{$\begin{array}{l}\text { Effective } \\
\text { Stress, } \sigma_{\mathbf{v}} \\
(\mathbf{k P a})\end{array}$} & \multirow[t]{2}{*}{$\begin{array}{l}\text { Void } \\
\text { Ratio, e }\end{array}$} & \multicolumn{2}{|c|}{$\begin{array}{l}\text { Coefficient of } \\
\text { Consolidation, } c_{v} \\
\left(\mathbf{m}^{2} / \mathbf{y r}\right)\end{array}$} & \multirow{2}{*}{$\begin{array}{l}\text { Coefficient } \\
\text { of Volume } \\
\text { Decrease, } \\
\mathbf{m}_{\mathbf{v}} \\
\left(\mathbf{m}^{2} / \mathbf{M N}\right)\end{array}$} & \multicolumn{2}{|c|}{$\begin{array}{l}\text { Hydraulic Conductivity, } \\
\text { k (m/s) }\end{array}$} \\
\hline & & $\log _{10}$ (time) & $\sqrt{\text { time }}$ & & $\log _{10}$ (time) & $\sqrt{\text { time }}$ \\
\hline 0 & 2.090 & - & - & - & - & - \\
\hline 1 & 2.028 & 3.91 & 5.64 & 6.537 & $7.95 \times 10^{-9}$ & $11.5 \times 10^{-9}$ \\
\hline 10 & 1.978 & - & 42.8 & 0.665 & - & $8.85 \times 10^{-9}$ \\
\hline 20 & 1.974 & - & 47.0 & 0.333 & - & $4.87 \times 10^{-9}$ \\
\hline 50 & 1.954 & - & 45.9 & 0.134 & - & $1.91 \times 10^{-9}$ \\
\hline 100 & 1.934 & - & 23.4 & 0.068 & - & $4.91 \times 10^{-9}$ \\
\hline Averages & & 3.91 & 33.0 & 1.547 & $7.95 \times 10^{-9}$ & $5.52 \times 10^{-9}$ \\
\hline
\end{tabular}

\subsection{Flume results}

\subsubsection{Open-ended beach profiles}

Figure 6 summarises all the open-ended, unflooded and flooded beach profiles obtained for Swanbank fly ash tested in the laboratory flume at initial \% solids of 55, 50, 45, 35 and $15 \%$. Clearly from Figure 5, the higher the initial \% solids, the steeper the beach profile (up to a maximum slope of about $1 \%$ for $55 \%$ solids, with $\leq 35 \%$ solids producing an almost flat beach). The average depth of the settled-out unflooded beach was between about 2 and $20 \mathrm{~mm}$, depending on the \% solids tested and hence the beach slope and, to a much lesser degree, whether or not a constriction was in place. The average depth of the settled-out unconstricted flooded beaches was between about 20 and $35 \mathrm{~mm}$, depending on the \% solids tested and hence the beach slope.

At 55\% solids, the steepest beach slope $(1.1 \%)$ occurs due to a constriction, and the flattest beach slope occurs due to flooding $(0.65 \%)$. At $\leq 50 \%$ solids, there is little distinction between beach profiles (with slopes ranging from $0.33-0.49 \%$ ), regardless of whether they are unflooded, flooded or constricted. The constriction has the effect of holding back the slurry, leading to a reduced beach slope before the constriction, and frees up the slurry flow beyond the constriction, leading to a steeper beach slope. The average beach slopes from the laboratory flume testing of Swanbank fly ash are presented in Figure 10, below, in which they are compared with the average field beach slope.

\subsubsection{Closed-ended backfilling}

Figure 7 shows the settled slurry profile resulting from closed-ended, flooded backfilling into two $50 \mathrm{~mm}$ high by $120 \mathrm{~mm}$ wide perimeter openings ( $40 \%$ opening), under a low head (initially $189 \mathrm{~mm}$, settling to $84 \mathrm{~mm}$ ) of Swanbank slurry initially at $50 \%$ solids. Figure 8 shows the settled slurry profile resulting from closed-ended, flooded backfilling into two $50 \mathrm{~mm}$ high by $100 \mathrm{~mm}$ wide openings, under a high head (initially $416 \mathrm{~mm}$, settling to $218 \mathrm{~mm}$ ) of Swanbank slurry initially at $50 \%$ solids. Figure 9 shows the settled slurry profile resulting from closed-ended, flooded backfilling into two $50 \mathrm{~mm}$ high by $100 \mathrm{~mm}$ wide openings, under a high head (initially $380 \mathrm{~mm}$, settling to $263 \mathrm{~mm}$ ) of Swanbank slurry initially at $60 \%$ solids. 


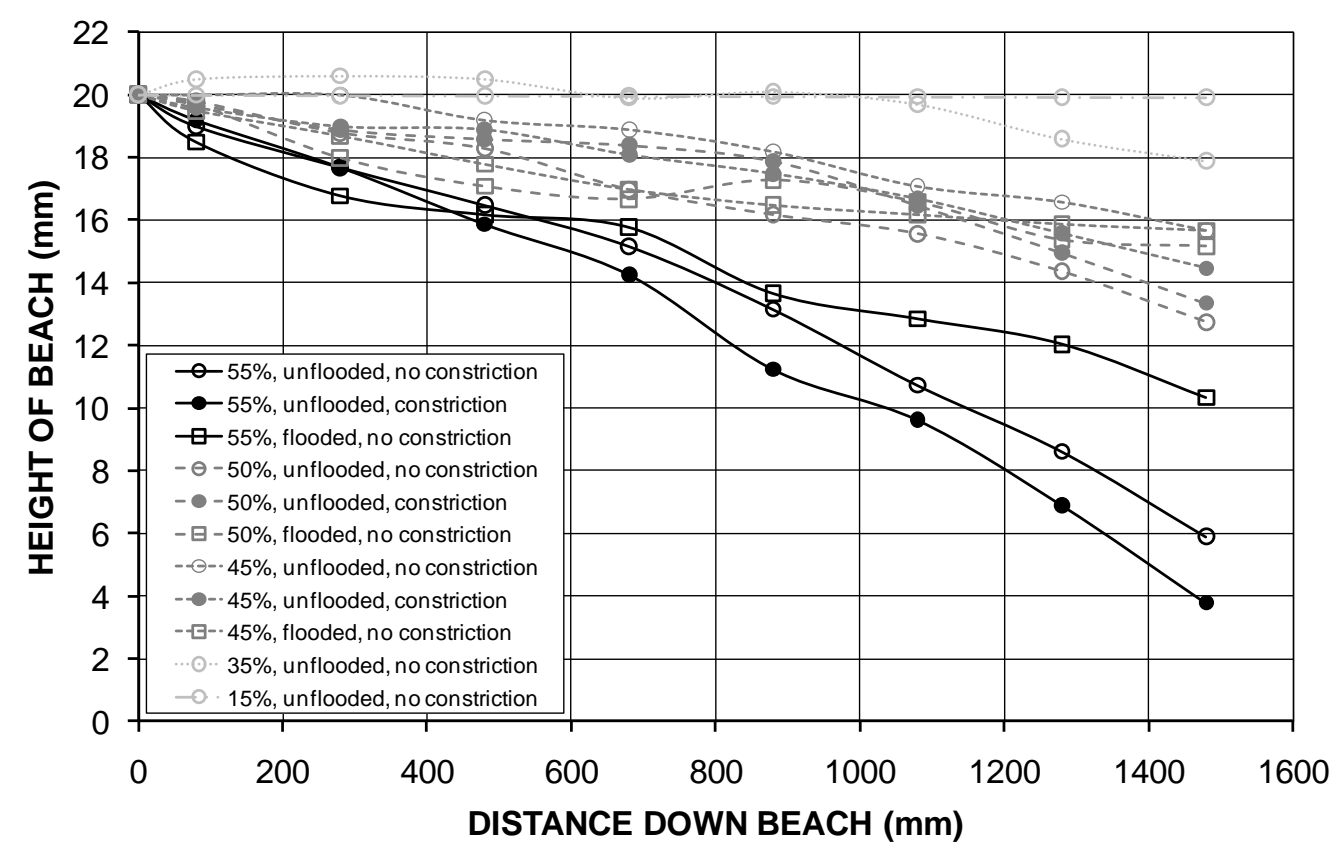

Figure 6 Summary of open-ended laboratory flume beach profiles for Swanbank fly ash

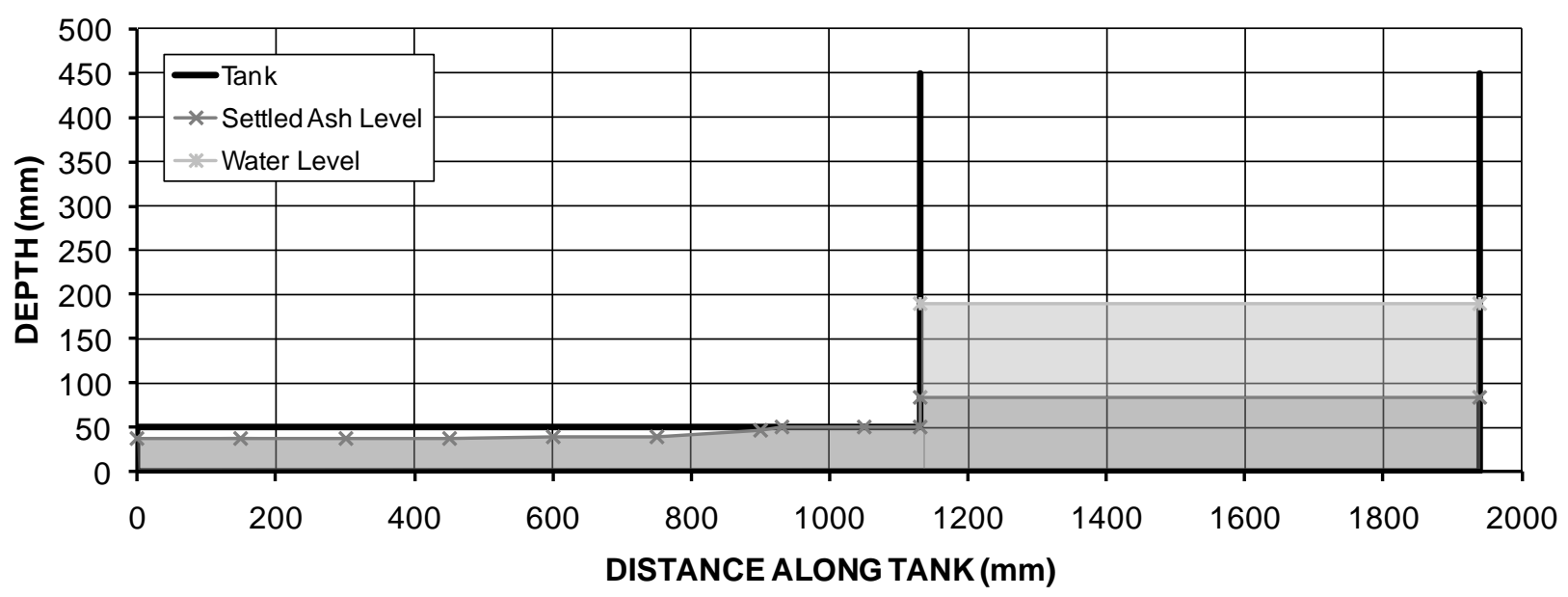

Figure 7 Closed-ended backfilling under a low head of Swanbank fly ash slurry, initially at 50\% solids

The results of the closed-ended, backfilling of constrictions under a head of slurry are summarised in Table 5 and Figure 10, which highlight the dramatic effect of applying a head of slurry in increasing the average final $\%$ solids and dry density, and driving the backfilling of the openings following initial settling of the slurry within them. Backfilling of the openings following initial settling of the slurry was observed to occur through fluidisation, whereby solids transferred into the openings while water was expelled. For 50-60\% solids initially, the applied head of slurry resulted in the $\%$ solids increasing from about $61 \%$ as measured in the settling columns to about $74 \%$, and the dry density increasing from about $0.9 \mathrm{~g} / \mathrm{cm}^{3}$ to about $1.2 \mathrm{~g} / \mathrm{cm}^{3}$, little affected by the initial \% solids over that range or by the height of the head of slurry applied. However, applying a high head of slurry appears most effective in driving backfilling of an opening, with a backfilled length of only about $300 \mathrm{~mm}$ under an initial head of slurry of $189 \mathrm{~mm}$, about $600 \mathrm{~mm}$ under $380 \mathrm{~mm}$ initial head, and about $750 \mathrm{~mm}$ under $416 \mathrm{~mm}$ initial head. The backfilled length was an average 1.7 times the initial head, 2.9 times the final head and 2.3 times the average head. 


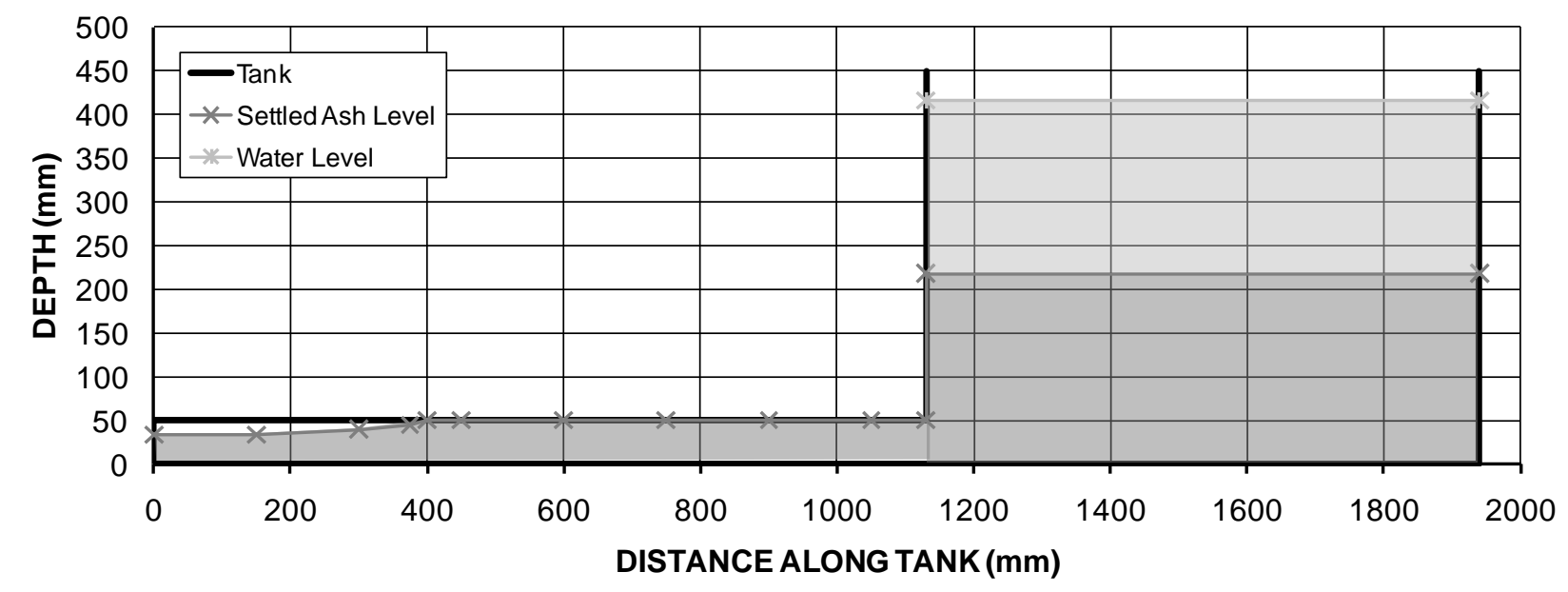

Figure 8 Closed-ended backfilling under a high head of Swanbank fly ash slurry, initially at 50\% solids

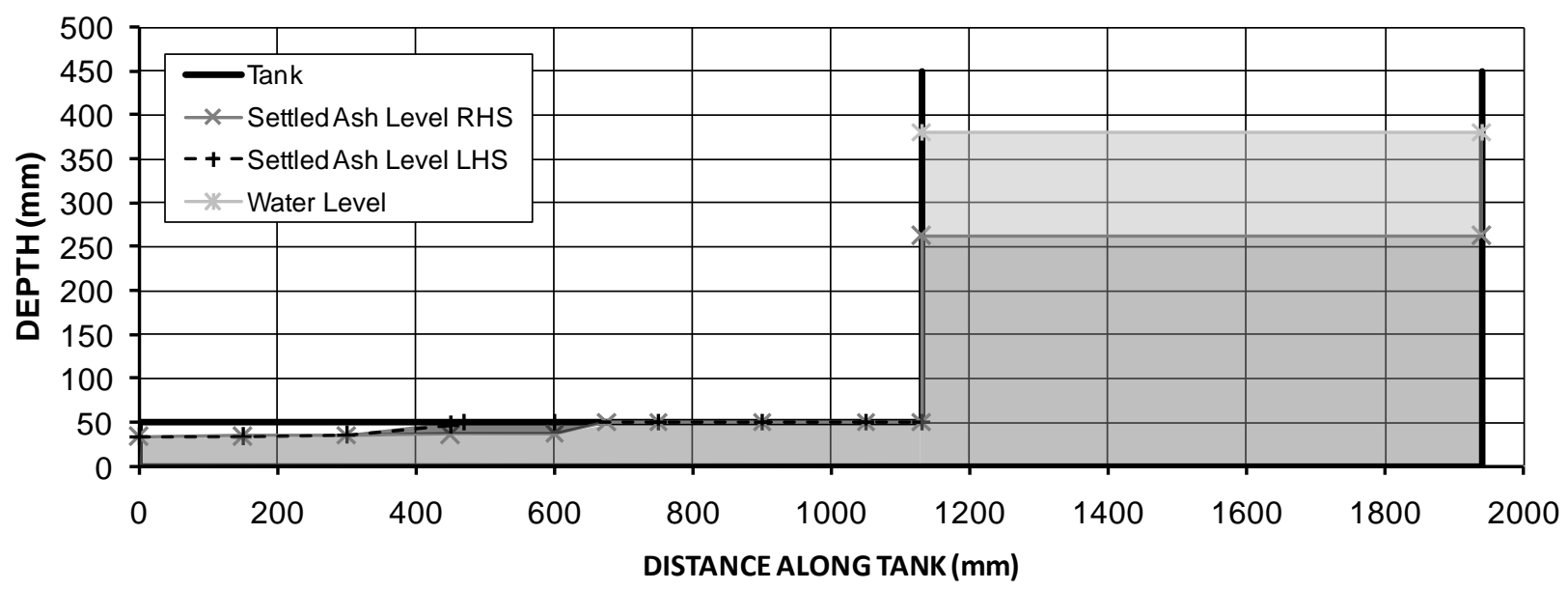

Figure 9 Closed-ended backfilling under a high head of Swanbank fly ash slurry, initially at $60 \%$ solids

\section{$4 \quad$ Field profiling, and sampling and laboratory testing}

The average beach slopes from the laboratory flume testing of Swanbank fly ash are presented in Table 6 and Figure 11, in which they are compared with the average field beach slope of about $0.15 \%$. The average slope of the field beach is similar to that of the laboratory flume beach formed with fly ash slurry at initially $15 \%$ solids, which is the approximate \% solids at which the fly ash is discharged in the field.

The total moisture content generally increased down the $355 \mathrm{~m}$ long beach from about $30 \%$ at the crest to about $42 \%$ at the toe. The range of particle size distributions obtained for the surface samples taken from the field beach are shown in Figure 12, together with the average particle size distribution curve obtained for the 200 L drum samples of Swanbank flay ash taken from the stockpile at Swanbank Power Station. Overall, the stockpiled fly ash shows a greater range of particle sizes, with both more fines and more coarse-grained particles than the range sampled from the entire beach. 
Table 5 Initial and final average \% solids, total moisture content and dry density on column settling, and on flume testing under a head of Swanbank fly ash slurry

\begin{tabular}{|c|c|c|c|c|c|}
\hline \multicolumn{2}{|c|}{ \% Solids } & \multicolumn{2}{|c|}{$\begin{array}{l}\text { Total Moisture } \\
\text { Content }(\%)\end{array}$} & \multicolumn{2}{|c|}{$\begin{array}{l}\text { Dry Density } \\
\left(\mathrm{g} / \mathrm{cm}^{3}\right)\end{array}$} \\
\hline Initial & Final & Initial & Final & Initial & Final \\
\hline \multicolumn{6}{|c|}{ On column settling (no excess head of fly ash slurry) } \\
\hline 55 & 61.7 & 45 & 38.3 & 0.771 & 0.909 \\
\hline 50 & 61.3 & 50 & 38.7 & 0.676 & 0.902 \\
\hline 45 & 60.7 & 55 & 39.3 & 0.588 & 0.888 \\
\hline 35 & 60.4 & 65 & 39.6 & 0.428 & 0.883 \\
\hline
\end{tabular}

Closed-ended backfilling under low head of slurry @ 50\% solids (initially $189 \mathrm{~mm}$, finally $84 \mathrm{~mm}$ )

\begin{tabular}{llllll}
\hline 50 & 75.6 & 50 & 24.4 & 0.676 & 1.248 \\
\hline
\end{tabular}

Closed-ended backfilling under high head of slurry @ 50\% solids (initially $416 \mathrm{~mm}$, finally $218 \mathrm{~mm}$ )

\begin{tabular}{llllll}
\hline 50 & 72.6 & 50 & 27.4 & 0.676 & 1.168 \\
\hline
\end{tabular}

Closed-ended backfilling under high head of slurry @ 60\% solids (initially $380 \mathrm{~mm}$, finally $263 \mathrm{~mm}$ )

\begin{tabular}{llllll}
\hline 60 & 74.4 & 40 & 25.6 & 0.873 & 1.215 \\
\hline
\end{tabular}

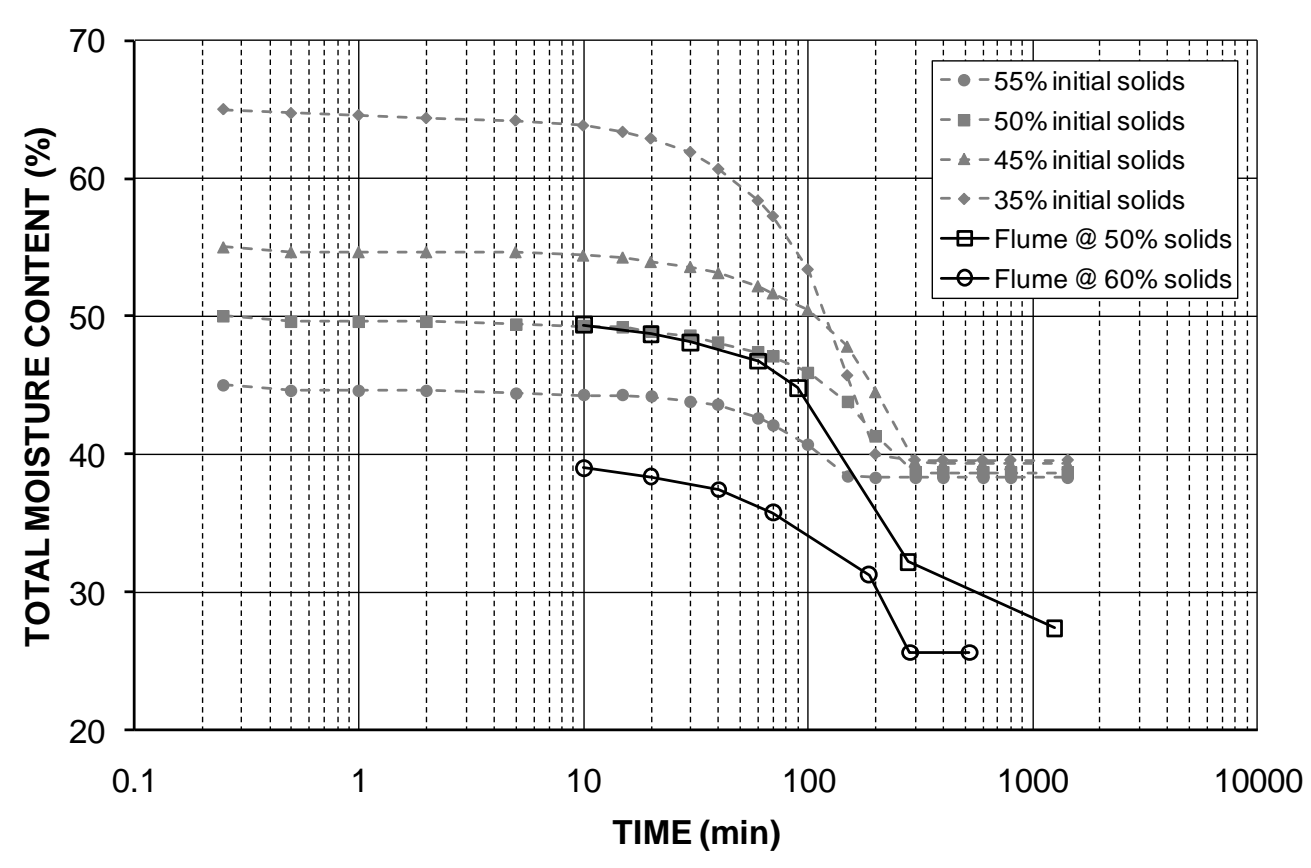

Figure 10 Comparison of Swanbank fly ash average total moisture contents on settling column, and flume testing under water and under a high head 
Table 6 Average slopes from laboratory flume and field Swanbank fly ash beaches

\begin{tabular}{lllll}
\hline Source & \% Solids & $\begin{array}{l}\text { Unflooded/ } \\
\text { Flooded }\end{array}$ & Constriction & $\begin{array}{l}\text { Average } \\
\text { Slope (\%) }\end{array}$ \\
\hline Laboratory flume & 55 & Unflooded & No & 0.953 \\
Laboratory flume & 55 & Unflooded & Yes & 1.096 \\
Laboratory flume & 55 & Flooded & No & 0.654 \\
Laboratory flume & 50 & Unflooded & No & 0.490 \\
Laboratory flume & 50 & Unflooded & Yes & 0.449 \\
Laboratory flume & 50 & Flooded & No & 0.327 \\
Laboratory flume & 45 & Unflooded & No & 0.293 \\
Laboratory flume & 45 & Unflooded & Yes & 0.374 \\
Laboratory flume & 45 & Flooded & No & 0.293 \\
Laboratory flume & 35 & Unflooded & No & 0.143 \\
Laboratory flume & 15 & Unflooded & No & 0.005 \\
Field & $\sim 15$ & Unflooded & No & 0.014 \\
\hline
\end{tabular}

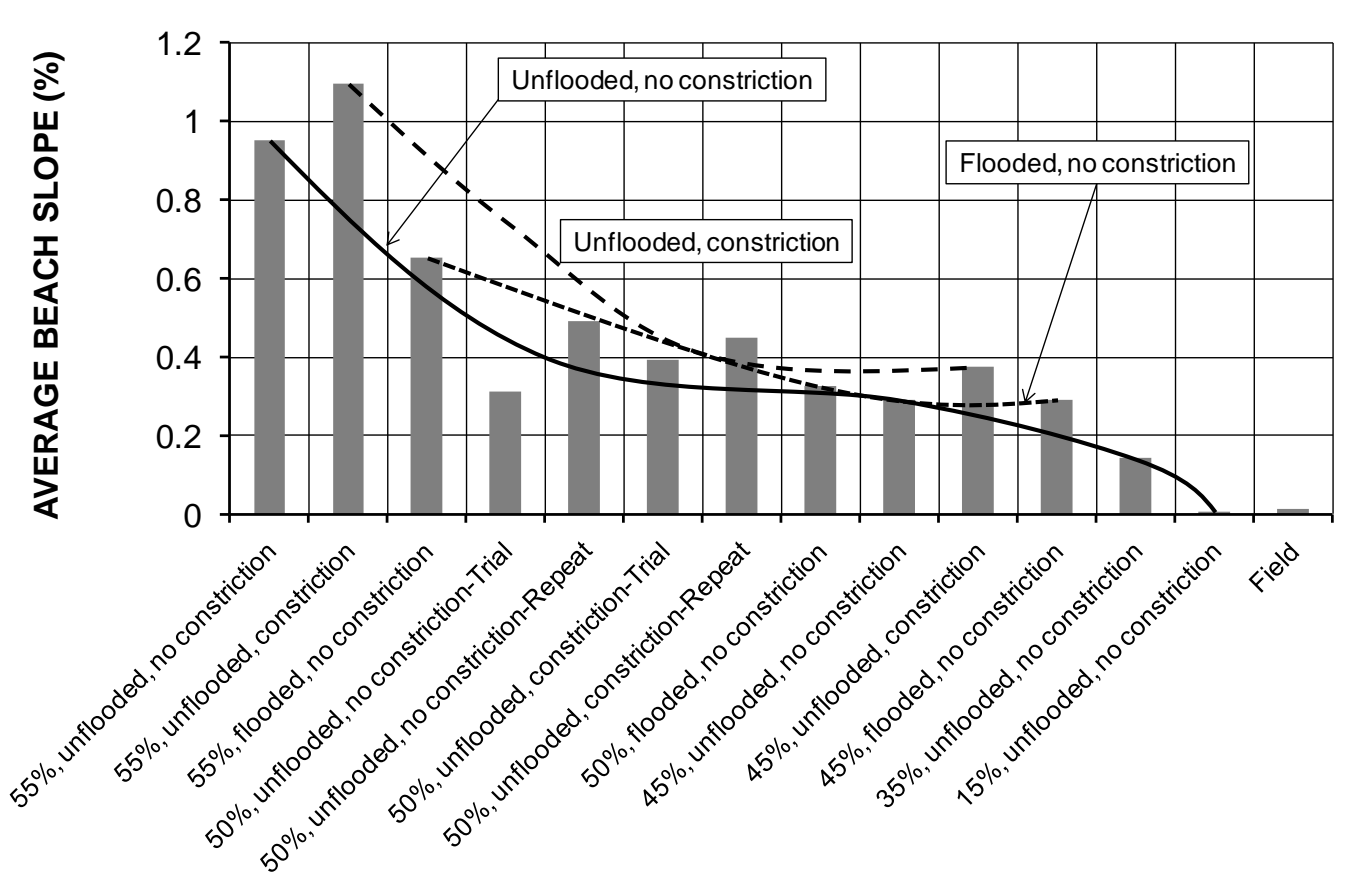

Figure 11 Average beach slopes from laboratory flume and field Swanbank fly ash beaches 


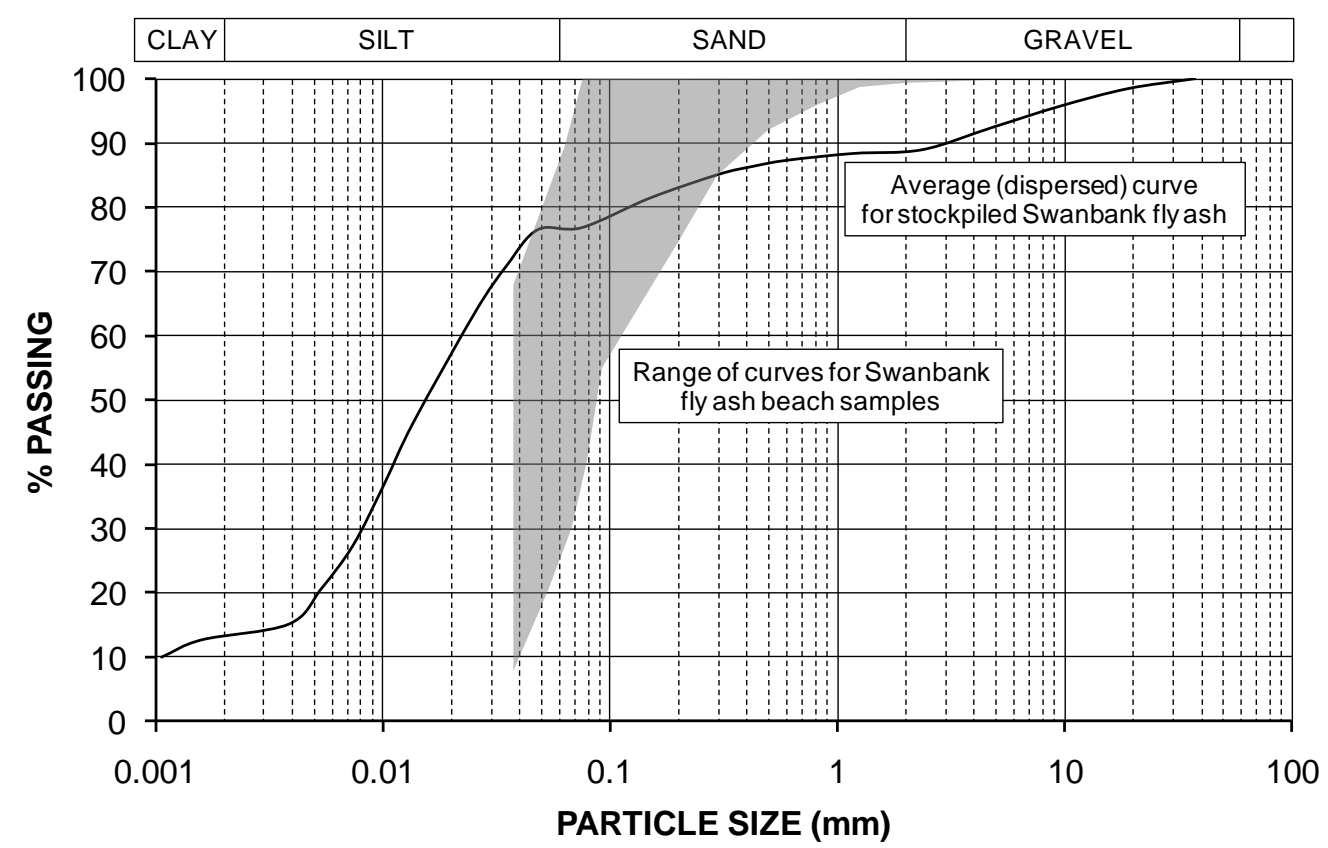

Figure 12 Particle size distribution curves for stockpile and beach samples of Swanbank fly ash

\section{Conclusions}

The compression and partial or complete collapse over time of the pillars supporting bord and pillar underground coal workings is reflected to the surface as subsidence and sinkholes, which limit the development of the surface or threaten any surface development present. Backfilling of the bord and pillar voids, for example with coal-fired power station fly ash, can be effective in providing the support necessary to limit or prevent surface subsidence and sinkholes, and hence allow the safe development of areas underlain by bord and pillar underground coal workings.

Swanbank fly ash was found to be a well-graded gravelly, clayey, sandy silt-sized material comprising spherical particles, with about $6 \%$ gravel-size, $17 \%$ sand-size, $64 \%$ silt-sized, and $13 \%$ clay-size particles. Swanbank fly ash was found to have an average liquid limit of $47.9 \pm 2 \%$, and to be non-plastic. It was found to have an average specific gravity of $2.09 \pm 0.02$, substantially less than that of normal mineral matter (being 2.65-2.7). Swanbank fly ash has an alkaline $\mathrm{pH}$ averaging $9.09 \pm 0.07$, and a moderate electrical conductivity averaging $351 \pm 25 \mu \mathrm{S} / \mathrm{cm}$.

Settling column testing of Swanbank fly ash slurry showed that the final \% solids decreased slightly with decreasing initial \% solids ( $61.7 \%$ solids from $55 \%$ solids initially to $60.4 \%$ solids from $35 \%$ solids initially). Oedometer testing of Swanbank fly ash initially at $50 \%$ solids indicated a very low compression index of 0.0455 , high coefficient of consolidation values averaging about $33 \mathrm{~m}^{2} /$ year, high coefficient of volume decrease values averaging about $1.5 \mathrm{~m}^{2} / \mathrm{MN}$ and low hydraulic conductivity values averaging about $5.5 \times 10^{-9} \mathrm{~m} / \mathrm{s}$.

Open-ended, unflooded, unconstricted laboratory flume tests on Swanbank fly ash slurries produced the steepest beach (averaging about $1 \%$ ) for an initial \% solids of 55\%, flatter beach slopes over the intermediate range of initial $\%$ solids tested that were relatively insensitive to the $\%$ solids over this range, and an essentially flat beach for $\leq 35 \%$ initial solids. The average field beach slope of $0.014 \%$ is similar to that obtained in the laboratory for an initial $15 \%$ solids (similar to the field initial \% solids). Unflooded, constricted laboratory flume tests on Swanbank fly ash slurries produced a slightly steeper beach at high initial \% solids, and only a very slightly steeper beach at intermediate initial \% solids. Flooding generally has little effect on the average beach slope for unconstricted beaching. These open-ended test results demonstrate that while Swanbank fly ash slurry of low initial \% solids would form an essentially flat beach, it would not be very effective in backfilling a large, unflooded or flooded underground void. The slurry would simply 
continue to flow, and would settle and consolidate, expelling bleed water above and beyond the sediment. Swanbank fly ash slurry of higher $\%$ solids forms a beach of about $1 \%$ average slope. While discharge at higher \% solids would reduce settling and consolidation, and drainage, it would also not be effective in backfilling a large, unflooded or flooded underground void, since the beach slope would prevent the complete filling of the void, and bleed water (albeit less) would still accumulate above and beyond the sediment.

Backfilling closed-ended, flooded constrictions under a head of slurry highlighted the dramatic effect of applying a head of slurry in increasing the average final \% solids and dry density, and driving the backfilling of the openings following initial settling of the slurry within them. Backfilling of the openings following initial settling of the slurry was observed to occur through fluidisation, whereby solids transferred into the openings while water was expelled. For 50-60\% initial \% solids, the applied head of slurry resulted in the \% solids increasing from about $61 \%$ as measured in the settling columns to about $74 \%$, and the dry density increasing from about $0.9 \mathrm{~g} / \mathrm{cm}^{3}$ to about $1.2 \mathrm{~g} / \mathrm{cm}^{3}$, little affected by the initial $\%$ solids over that range or by the height of the head of slurry applied. However, applying a high head of slurry appears most effective in driving backfilling of an opening, with a backfilled length of only about $300 \mathrm{~mm}$ under an initial head of slurry of $189 \mathrm{~mm}$, about $600 \mathrm{~mm}$ under $380 \mathrm{~mm}$ initial head, and about $750 \mathrm{~mm}$ under $416 \mathrm{~mm}$ initial head. The backfilled length was an average 1.7 times the initial head, 2.9 times the final head and 2.3 times the average head.

Based on the laboratory test results and their interpretation, the following guidelines are offered for the backfilling of bord and pillar voids using fly ash slurry:

1. Voids should first be blocked off downslope of the delivery point for the fly ash slurry, to contain the slurry.

2. The optimum initial $\%$ solids for the fly ash slurry appears to be in the range from $50-60 \%$, to ensure that it will readily flow, to maximise initial filling, to make the slurry more capable of fluidising to facilitate void filling following settling, and to increase the final dry density, strength and stiffness achieved. The optimal initial \% solids will increase with the applied head of fly ash.

3. A head of slurry should be applied in the borehole used to deliver the fly ash slurry, which will facilitate void filling and gain in dry density, strength and stiffness.

\section{Acknowledgements}

The Queensland Department of Employment, Economic Development and Innovation (DEEDI) contributed funding towards the laboratory testing and reporting on which this paper is based, through CSIRO's Queensland Centre for Advanced Technologies, and DEEDI gave permission for the results to be published. The laboratory testing was carried out within the Golder Geomechanics Centre at The University of Queensland, largely by Mokshadsing Ramlackhan and Daniel Spriggs, as part of their Fourth Year Civil Engineering Thesis. The authors are grateful to the staff of Swanbank Power Station for facilitating sampling of Swanbank fly ash.

\section{References}

ACARP Project C7033 (2001) Utilising Fly Ash Paste Backfill.

AS 1289, Methods of Testing Soils for Engineering Purposes, Standards Australia.

Dodd, W.E. (2005) Fly ash use in pressurised grout remote backfilling of abandoned underground mines in North Dakota, Interstate Technical Group on Abandoned Underground Mines Third Biennial Workshop.

Skempton, A.W. (1969) The consolidation of clays by gravitational compaction, Quarterly Journal of the Geological Society, Vol. 125, pp. 373-411.

Wald, S. and Beechie, B. (1996) Fly ash grout testing in a simulated wet mine environment, in Proceedings 18th Annual Conference of the Association of Abandoned Mine Lands, Kalispell, Montana, September 15-18, 1996.

Ward, C.R., French, D., Jankowski, J., Riley, K. and Li, Z. (2006) Use of coal ash in mine backfill and related applications, Research Report 62, CRC for Coal in Sustainable Development, Queensland Centre for Advanced Technologies. 